\title{
PROMOÇÃO DE SAÚDE BUCAL NOS MUNICÍPIOS DE DOUTOR ULYSSES E ADRIANÓPOLIS
}

Caio César BARTENACK, Juliane Slembarski MACHADO, Giovana PECHARKI, Luciana SCHNEIDER, Marilene BUFFON

O presente projeto de extensão tem por objetivo promover ações de promoção da saúde bucal no Vale do Ribeira, permitindo ao acadêmico de Odontologia da UFPR desenvolver as competências e habilidades para aplicá-lo na prática odontológica, em ambiente comunitário, dirigindo sua formação para a transformação da realidade. As atividades desenvolvidas envolveram os municípios de Doutor Ulysses e Adrianópolis. No município de Doutor Ulysses houve a participação dos acadêmicos do penúltimo e do último período do curso de Odontologia, exercendo atividades no serviço de atenção básica do município, realizando atividades educativas, preventivas e curativas na população local. $O$ público-alvo assistido foi a população que buscou o serviço de atenção básica na Unidade de Saúde (US) e também os escolares do município. As atividades foram realizadas dentro da US e nos Equipamentos Sociais. E no município de Adrianópolis foi realizado levantamento das condições de saúde geral das crianças da APAE como parte do diagnóstico situacional em saúde do município. O projeto proporcionou ao acadêmico o conhecimento da realidade local, da relação entre a condição de vida da população e seus agravos à saúde bucal, bem como, da organização da atenção à saúde bucal em municípios de pequeno porte.

Palavras-chave: saúde bucal; atenção básica, Unidade de Saúde. 